\title{
Insights into kinetic inhibition effects of MEG, PVP, and L-tyrosine aqueous solutions on natural gas hydrate formation
}

\author{
Amir Saberi ${ }^{1,2} \cdot$ Abdolmohammad Alamdari $^{1}$ - Ali Rasoolzadeh ${ }^{1} \cdot$ Amir H. Mohammadi $^{3}$
}

Received: 2 November 2019 / Published online: 1 October 2020

(c) The Author(s) 2020

\begin{abstract}
It is necessary to understand all the prerequisites, which result in gas hydrate formation for safe design and control of a variety of processes in petroleum industry. Thermodynamic hydrate inhibitors (THIs) are normally used to preclude gas hydrate formation by shifting hydrate stability region to lower temperatures and higher pressures. Sometimes, it is difficult to avoid hydrate formation and hydrates will form anyway. In this situation, kinetic hydrate inhibitors (KHIs) can be used to postpone formation of gas hydrates by retarding hydrate nucleation and growth rate. In this study, two kinetic parameters including natural gas hydrate formation induction time and the rate of gas consumption were experimentally investigated in the presence of monoethylene glycol (MEG), L-tyrosine, and polyvinylpyrrolidone (PVP) at various concentrations in aqueous solutions. Since hydrate formation is a stochastic phenomenon, the repeatability of each kinetic parameter was evaluated several times and the average values for the hydrate formation induction times and the rates of gas consumption are reported. The results indicate that from the view point of hydrate formation induction time, $2 \mathrm{wt} \% \mathrm{PVP}$ and $20 \mathrm{wt} \%$ MEG aqueous solutions have the highest values and are the best choices. It is also interpreted from the results that from the view point of the rate of gas consumption, $20 \mathrm{wt} \%$ MEG aqueous solution yields the lowest value and is the best choice. Finally, it is concluded that the combination of PVP and MEG in an aqueous solution has a simultaneous synergistic impact on natural gas hydrate formation induction time and the rate of gas consumption. Furthermore, a semi-empirical model based on chemical kinetic theory is applied to evaluate the hydrate formation induction time data. A good agreement between the experimental and calculated hydrate formation induction time data is observed.
\end{abstract}

Keywords Gas hydrate $\cdot$ Clathrate hydrate $\cdot$ Natural gas $\cdot$ Kinetic hydrate inhibitor $(\mathrm{KHI}) \cdot$ Induction time $\cdot$ Kinetics

\section{List of symbols \\ MEG Monoethylene glycol \\ K Kelvin \\ KHI Kinetic hydrate inhibitor \\ PEO Polyethylene oxide \\ PVCap Polyvinylcaprolactam}

Edited by Yan-Hua Sun

Amir H. Mohammadi

amir_h_mohammadi@yahoo.com

1 Department of Natural Gas Engineering, School of Chemical and Petroleum Engineering, Shiraz University, Shiraz 71345, Iran

2 Department of Process Engineering, National Iranian Gas Company (NIGC), South Pars Gas Complex (SPGC) Phases 4\&5, Bushehr 75391/311, Iran

3 Discipline of Chemical Engineering, School of Engineering, University of KwaZulu-Natal, Howard College Campus, King George V Avenue, Durban 4041, South Africa
PVP Polyvinylpyrrolidone

rpm Round per minute

SNG Synthetic natural gas

THI Thermodynamic hydrate inhibitor

$A_{1}-A_{5} \quad$ Optimized parameter

AAE Average absolute error

AARE Average absolute relative error

$B^{0} \quad$ Nucleation rate

$b \quad$ Arbitrary fitting constant

C Arbitrary constant

$k \quad$ Arbitrary fitting constant

$m \quad$ Fitting parameter

$m . f_{\mathrm{PVP}} \quad$ Mass fraction of PVP in aqueous solution

$m . f_{\text {MEG }}$ Mass fraction of MEG in aqueous solution

$N_{\mathrm{A}} \quad$ Avogadro number

$N_{\mathrm{p}} \quad$ Number of data points

$n \quad$ Arbitrary fitting constant

$n_{\text {cell }}^{t=0} \quad$ Initial mole of gas in the cell

$n_{\text {cell }}{ } \quad$ Mole of gas at time $t$ 


$\begin{array}{ll}P & \text { System's initial pressure in MPa } \\ P_{\mathrm{c}} & \text { Critical pressure } \\ P_{\text {cell }} & \text { Cell pressure } \\ R & \text { Universal gas constant } \\ r & \text { Arbitrary fitting constant } \\ S & \text { Supersaturation ratio } \\ T_{\mathrm{c}} & \text { Critical temperature } \\ T_{\text {cell }} & \text { Cell temperature } \\ T_{\mathrm{s}} & \text { Gas hydrate phase equilibrium temperature } \\ T_{\text {target }} & \text { Cell temperature, which is kept constant for } \\ & \text { hydrate to form } \\ t_{\mathrm{i}} & \text { Induction time } \\ \Delta T & \text { Degree of subcooling } \\ \Delta t & \text { Time interval between two experiments } \\ V_{\text {cell }} & \text { Cell volume } \\ V_{\mathrm{M}} & \text { Crystal molar volume } \\ Z_{\text {cell }} & \text { Compressibility factor of gas } \\ \delta & \text { Arbitrary fitting constant } \\ \sigma & \text { Average surface tension on the liquid-solid } \\ \lambda & \text { interface } \\ \lambda & \text { Arbitrary fitting constant } \\ \omega & \text { Acentric factor } \\ \vartheta & \text { Number of ions per dissolved molecule }\end{array}$

\section{Introduction}

Natural gas is the cleanest fossil fuel that has been widely used in various applications. The irregular, uncontrolled, and vast consumption of natural gas will make this type of energy resource coming to end in future. Therefore, it necessitates employing safe and efficient methods in exploitation, processing, transportation, storage, and delivery of natural gas. One of the major obstacles that is likely to threaten natural gas flow assurance is gas hydrates, or clathrate hydrates, which can form inside pipelines, valves, cold boxes, and other production and processing facilities (Villicaña-García and Ponce-Ortega 2019; Rimos et al. 2014). For gas hydrates to form, several conditions have to be prepared such as high pressures, existence of sufficient amounts of water in the form of water vapor, liquid water, or ice called the host molecules and existence of some small and light molecules of gases and volatile liquids, which play roles of the guest molecules (Sloan and Koh 2008). Gas hydrates crystalline lattices formed by water molecules can be stabilized by occupation of cavities with guest molecules (Sloan and Koh 2008).

Gas hydrate formation in pipelines can cause blockage and sudden pressure drops and huge economic losses are the results of this phenomenon (Sloan and Koh 2008; Hammerschmidt 1934). Heating, pressure reduction, water removal, and injecting some kinds of inhibitors to pipelines are some recommended methods to avoid gas hydrate formation.
Among all the aforementioned methods, injecting hydrate inhibitors is more possible and easy to use way (Sloan and Koh 2008). In traditional form, two types of hydrate inhibitors are utilized for industrial applications: Thermodynamic hydrate inhibitors (THIs) tend to decrease water activity and shift hydrate phase equilibrium curve to lower temperatures and higher pressures. Examples of this type of inhibitors are methanol, ethanol, monoethylene glycol (MEG), sodium chloride $(\mathrm{NaCl})$, etc. (Sloan and Koh 2008; Ghaedi et al. 2018; Masoudi et al. 2005; Najibi et al. 2013; Haghighi et al. 2009; Lee and Kang 2011; Hemmingsen et al. 2011; Moeini et al. 2018). On the other hand, there are kinetic hydrate inhibitors (KHIs) that act differently. They increase hydrate formation induction time and decrease hydrate nucleation and crystal growth rates. The well-known KHIs are polyvinylpyrrolidone (PVP) and polyvinylcaprolactam (PVCap) (Sloan and Koh 2008; Daraboina et al. 2011, 2013; Kelland 2006; Salamat et al. 2013; Villano et al. 2009; Rasoolzadeh et al. 2016; Cha et al. 2013; Kakati et al. 2016). THIs are normally used in large quantities even up to $50 \mathrm{wt} \%$ but in some specific cases, injecting THIs in large quantities has an insufficient impact on gas hydrate formation because the conditions are very convenient for gas hydrates to form. In these cases, KHIs can be used to delay formation of gas hydrates, as mentioned earlier (Sloan and Koh 2008). One can define the induction time as an interval between reaching hydrate formation conditions and occurring hydrate formation (Sloan and Koh 2008; Daraboina et al. 2011; Daraboina et al. 2013; Kelland 2006; Salamat et al. 2013; Villano et al. 2009; Rasoolzadeh et al. 2016; Cha et al. 2013; Kakati et al. 2016). In the past decade, the focus of scientific investigations was on the new group of inhibitors like some kinds of ionic liquids (ILs) that not only shift hydrate phase equilibrium curve to lower temperature/higher pressure regions but also increase hydrate formation induction time. These compounds are called dual function inhibitors (DFIs) (Rasoolzadeh et al. 2016). A large number of studies of DFIs are available in the literature. Xiao et al. investigated the inhibition performances of imidazolium-based ILs on methane and natural gas hydrates formation. They concluded that the used ILs (due to strong electrostatic charges and hydrogen bonds) not only shift the hydrate equilibrium curve/hydrate dissociation conditions to lower temperatures and higher pressures but also slow down the hydrate nucleation and growth rate (Xiao and Adidharma 2009; Xiao et al. 2010). Kim et al. synthesized pyrrolidinium cation-based ILs and studied their thermodynamic and kinetic impacts on methane hydrate formation. They also observed the dual-function inhibition impacts of the pyrrolidinium cation-based ILs on methane hydrate (Kim et al. 2011). Tariq et al. reviewed the roles of ILs on gas hydrate formation. They reviewed all of the available kinetic and thermodynamic hydrate inhibition data in the attendance of ILs to evaluate the strength of 
each IL on gas hydrate inhibition (Tariq et al. 2014). Lim et al. used morpholine as a DFI for gas hydrate formation. They applied the powder X-ray diffraction, Raman spectroscopy, and nuclear magnetic resonance (NMR) analyses to investigate molecular behavior and the crystal structure of hydrate in the presence of morpholine (Lim et al. 2014). Qureshi et al. studied kinetic and thermodynamic effects of polyethylene oxide (PEO) and vinyl caprolactam (VCap) with two ILs on synthetic natural gas hydrate formation. They took into account that the addition of the synergents to the ILs could effectively improve the gas hydrate inhibition strength of the ILs (Qureshi et al. 2016). Lee et al. evaluated dual-function inhibition performances of ILs in the presence/absence of polyvinyl caprolactam (PVCap) on methane hydrate formation. They observed that the utilization of IL and PVCap mixture results in the enhanced kinetic inhibition effect on methane hydrate formation (Lee et al. 2016). Haji Nasrollahebrahim et al. investigated thermo/ kinetic inhibition effects of six ILs on methane hydrate formation by molecular dynamics simulation. They concluded that among the investigated ILs, 1-(2-hydroxyethyl)-3-methylimidazolium bis(fluorosulfonyl)imide $\left(\left[\mathrm{C}_{2} \mathrm{OHmim}\right]\left[\mathrm{f}_{2} \mathrm{~N}\right]\right)$ and 1-(2,3-dihydroxypropyl)-3 methylimidazoliumbis(fluoro sulfonyl)imide $\left(\left[\mathrm{C}_{3}(\mathrm{OH})_{2} \mathrm{mim}\right]\left[\mathrm{f}_{2} \mathrm{~N}\right]\right)$ have stronger thermodynamic/kinetic inhibition effects (Haji Nasrollahebrahim et al. 2013). Yaqub et al. reviewed the roles of DFIs on gas hydrate inhibition. They calculated the average temperature depression and relative inhibition power for various ILs for selection of the best IL for academic and industrial applications (Yaqub et al. 2018). Khan et al. experimentally studied inhibition strength of tetramethyl ammonium chloride (TMACl) on the formation of methane and carbon dioxide hydrates. They used 1, 5, and $10 \mathrm{wt} \% \mathrm{TMACl}$ aqueous solution and concluded that TMACl can be used as potential DFI for both methane and $\mathrm{CO}_{2}$ hydrates (Khan et al. 2019).

Although the investigations into THIs and KHIs are abundant, there is limited information on the mixed solutions of THIs and KHIs. Daraboina et al. experimentally studied the impacts of polyethylene oxide (PEO) and $\mathrm{NaCl}$ on the performance of Luvicap to inhibit natural gas hydrate formation. They concluded that the addition of PEO and $\mathrm{NaCl}$ on Luvicap decreases the nucleation of hydrate, which means the enhancement of inhibition strength of Luvicap (Daraboina et al. 2013). Cha et al. experimentally investigated the inhibition effects of MEG and PVP on synthetic natural gas (SNG) hydrate formation. They stated that the kinetic inhibition effect of MEG is an important factor in decreasing MEG injection for offshore petroleum pipelines (Cha et al. 2013). Kakati et al. performed an experimental study of the addition of L-tyrosine and $\mathrm{NaCl}$ to PVP as a widely-used gas hydrate inhibitor to study its performance on (methane-ethane-propane) gas mixture hydrates. They observed that the addition of L-tyrosine and $\mathrm{NaCl}$ on PVP leads to a synergistic effect on hydrate inhibition (Kakati et al. 2016). Kim et al. conducted an experimental study on hydrate formation of SNG in the presence of MEG and PVCap. They suggested that mixing small amounts of PVCap with MEG leads to a synergistic effect on hydrate inhibition and the amounts of MEG can be reduced substantially (Kim et al. 2014).

This contribution is intended to experimentally evaluate the performances of KHIs, THIs, and their mixtures on natural gas hydrate formation kinetic parameters like induction time and the rate of gas consumption. Several mixtures at various experimental conditions were applied for this purpose. MEG was used as THI, PVP and L-tyrosine were used as KHIs in this work. Moreover, for the case of MEG and PVP, a partly empirical model based on the chemical kinetics theory was handled to correlate the natural gas hydrate formation induction time data.

\section{Experimental}

\subsection{Materials}

Monoethylene glycol (MEG) (99.5\% purity) and L-tyrosine (99.0 wt\% purity) were purchased from Merck. Polyvinylpyrrolidone (PVP) (99.0 wt\% purity) was purchased from Sigma-Aldrich, with a molecular mass of $40,000 \mathrm{~g} / \mathrm{mol}$.

The natural gas mixture was purchased from Fara Fan Gas and its composition is shown in Table 1. Deionized water was used in the experiments.

MEG in mass fractions of 0.10 and 0.20 , PVP and L-tyrosine in mass fractions of 0.01 and 0.02 were used in this work. The aqueous solutions were prepared by the gravimetric method using the electronic A\&D balance (EK-300) with $\pm 0.01 \mathrm{~g}$ readability.

\subsection{Apparatus}

A $250 \mathrm{~cm}^{3}$ stainless steel (SS-316) cell is an important part of the experimental equipment, which can tolerate pressures up to $35 \mathrm{MPa}$. Circulation of water and ethylene glycol

Table 1 Composition of natural gas mixture used in this study

\begin{tabular}{ll}
\hline Component & Mole fraction \\
\hline $\mathrm{CH}_{4}$ & 0.8040 \\
$\mathrm{C}_{2} \mathrm{H}_{6}$ & 0.1030 \\
$\mathrm{C}_{3} \mathrm{H}_{8}$ & 0.0500 \\
$n-\mathrm{C}_{4}$ & 0.0072 \\
$i-\mathrm{C}_{4}$ & 0.0165 \\
$\mathrm{~N}_{2}$ & 0.0011 \\
$\mathrm{CO}_{2}$ & 0.0182 \\
\hline
\end{tabular}


aqueous solution in the constant-temperature bath controls the cell temperature. A high-precision temperature sensor with $\pm 0.1 \mathrm{~K}$ readability was used to measure the cell temperature. A piezoresistive pressure transducer (Keller, 23S) was applied to measure the cell pressure, with a standard uncertainty of $\pm 0.015 \%$ of total pressure. A magnetic stirrer was used to agitate the fluid and solid hydrate phases in the vessel at a speed of $500 \mathrm{rpm}$. The setup also consists of a data acquisition program to log several parameters like pressure, temperature, and stirrer speed at every few seconds. Figure 1 demonstrates a schematic view of the setup.

\subsection{Procedure}

After washing and drying the experimental cell, a leakage test was performed by injecting nitrogen at $1 \mathrm{MPa}$. Afterward, all the remained gases in the cell were removed using a two-stage rotary vacuum pump (Adixen Pascal Series 2005SD) for about half an hour. Then, $50 \mathrm{~cm}^{3}$ of an aqueous solution as a feed was injected into the cell. The pressure of the vessel was adjusted to the desired pressure through the gas injection. To avoid gas hydrate memory effect, the temperature of the cell was elevated to $313 \mathrm{~K}$ and kept constant (313 K) for 30 min while the stirrer rotated at the constant rate of $500 \mathrm{rpm}$. The bath temperature was set to two distinct targets temperatures of 277.15 and $280.15 \mathrm{~K}$ for each experiment. The cell temperature decreased from $313 \mathrm{~K}$ to the target temperatures with the cooling rate of $0.3 \mathrm{~K} \mathrm{~min}^{-1}$ and gave enough time to ensure gas hydrate formation completion. Finally, the system temperature increased to $313 \mathrm{~K}$ and the next test was performed.

\section{Induction time and gas consumption rate modeling}

The rate of gas consumption can be determined using the following procedure:

Step 1 The initial mole of gas in the cell is calculated as follow (Rasoolzadeh et al. 2016):

$n_{\text {cell }}^{t=0}=\frac{\left(P_{\text {cell }}^{t=0}\right)\left(V_{\text {cell }}^{t=0}\right)}{R\left(T_{\text {cell }}^{t=0}\right)\left(Z_{\text {cell }}^{t=0}\right)}$

where $P_{\text {cell }}$ is the cell pressure, $V_{\text {cell }}$ stands for the cell volume $\left(250 \mathrm{~cm}^{3}\right), R$ represents the universal gas constant, $T_{\text {cell }}$ designates the cell temperature and $Z_{\text {cell }}$ indicates the compressibility factor of the gas mixture, which is calculated using the Peng-Robinson equation of state and the van der Waals (vdW) mixing rules (Peng and Robinson 1976).

Step 2 After completion of hydrate formation, the mole of gas is calculated thusly (Rasoolzadeh et al. 2016, 2019; Aliabadi et al. 2015):

$n_{\text {cell }}{ }^{t}=\frac{\left(P_{\text {cell }}{ }^{t}\right)\left(V_{\text {cell }}{ }^{t}\right)}{R\left(T_{\text {cell }}{ }^{t}\right)\left(Z_{\text {cell }}{ }^{t}\right)}$

Step 3 The rate of gas consumption at time $t$ can be calculated as follow (Rasoolzadeh et al. 2016):

$v_{\mathrm{g}}=\frac{n_{\text {cell }}{ }^{t=0}-n_{\text {cell }}{ }^{t}}{\Delta t}$

where $v_{\mathrm{g}}$ is the rate of gas consumption.

After completion of hydrate formation, the gas phase composition changes, and to calculate the number of moles, the

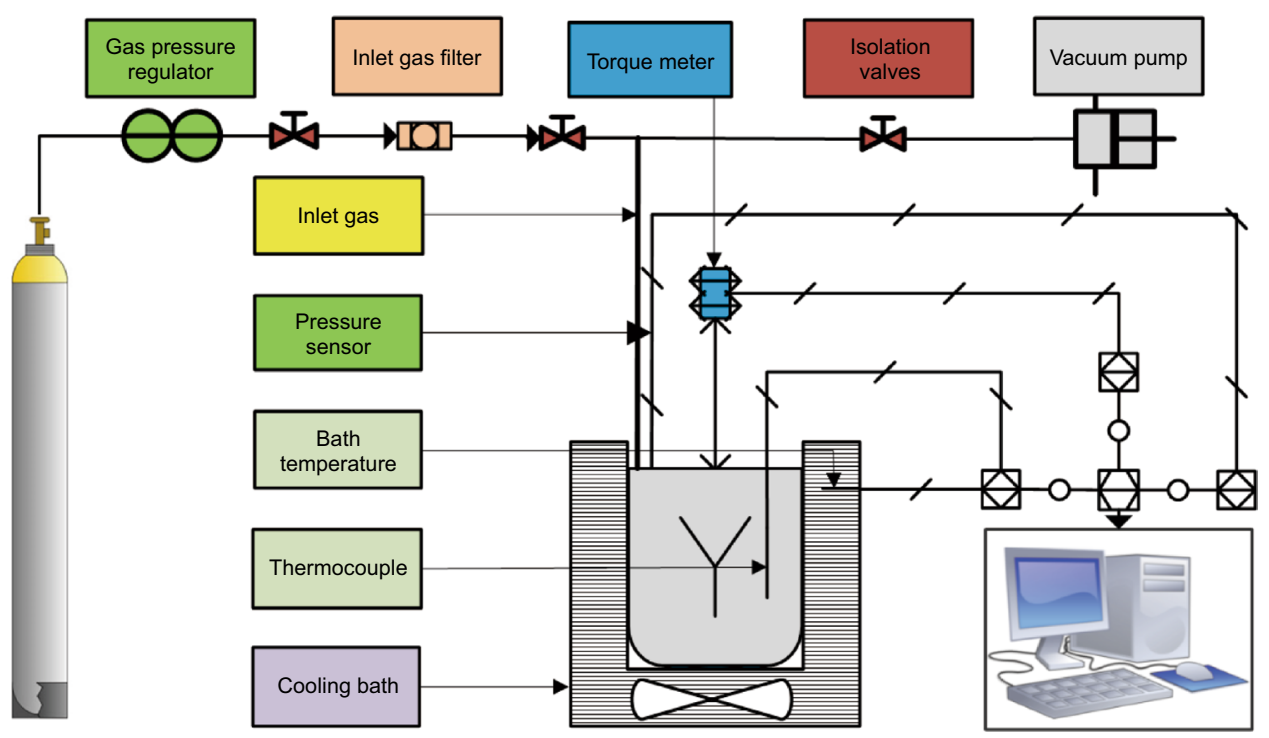

Fig. 1 The simplified arrangement of the experimental setup 
gas phase composition should be included. We had no equipment to measure the gas phase composition. It requires a gas chromatography (GC) analyzer connected to the cell to exactly measure the gas phase composition. Because of the lack of equipment, it was assumed that the composition of the gas mixture is constant. Table 2 presents the critical properties and the acentric factors of the gas mixture components required to calculate the compressibility factor of the gas mixture.

The nucleation rate has the inverse relationship with supersaturation (Rasoolzadeh et al. 2016; McCabe and Stevens 1951; Mullin 1993):

$B^{0}=C \exp \left[-\frac{16 \pi \sigma^{3} V_{\mathrm{M}}^{2} N_{\mathrm{A}}}{3 \vartheta^{2}(R T)^{3} S^{2}}\right]$

where $B^{0}$ stands for the nucleation rate, $N_{\mathrm{A}}$ is Avogadro number, $R$ represents the universal gas constant, as mentioned earlier, $V_{\mathrm{M}}$ and $\sigma$ represent the crystal molar volume and the average surface tension on the liquid-solid interface, respectively. $C$ is an arbitrary constant, $S$ denotes the supersaturation ratio and $\vartheta$ is the number of ions per dissolved molecule. Equation (4) can be re-written as follows (Rasoolzadeh et al. 2016):

$B^{0}=k \exp \left(-\frac{b}{S}\right)^{n}$

where $k, b$, and $n$ are arbitrary fitting constants.

It is obvious that there is an inverse relation between the induction time and the nucleation rate (Rasoolzadeh et al. 2016; Natarajan 1993):

$t_{\mathrm{i}}=\frac{\delta}{\left(B^{0}\right)^{r}}$ where $t_{\mathrm{i}}$ represents the induction time; $r$ and $\delta$ are arbitrary constants. Rearranging Eqs. (5) and (6) leads to the following relation (Rasoolzadeh et al. 2016):

$t_{\mathrm{i}}=\frac{\delta}{\left[k \exp \left(-\frac{b}{S}\right)^{n}\right]^{r}}=\frac{\delta}{k^{r}} \times \frac{1}{\exp \left(-\frac{b}{S}\right)^{n r}}$

$\lambda=\frac{\delta}{k^{r}}$

$m=n r$

$t_{\mathrm{i}}=\lambda \exp \left(-\frac{b}{S}\right)^{-m}$

We considered the dimensionless subcooling as the supersaturation driving force and hydrate nucleation. Therefore, Eq. (10) is converted to the following form (Rasoolzadeh et al. 2016):

$t_{\mathrm{i}}=\lambda \exp \left(\frac{b T_{\mathrm{s}}}{\Delta T}\right)^{-m}$

where $\lambda$ is a function of the aqueous solution molecular weight, MEG mass fraction, PVP mass fraction, and the system initial pressure; $m$ and $b$ are the fitting parameters that are optimized using the gas hydrate formation induction time data; $T_{\mathrm{s}}$ is the gas hydrate phase equilibrium temperature that can be calculated using the van der Waals-Platteeuw (vdW-P)-based model (Sloan and Koh 2008) presented in our previous work (Saberi et al. 2018); $\Delta T$ is the difference between the hydrate phase equilibrium temperatures. $\lambda$ is defined as follows:

$\lambda=A_{1}+\left[A_{2} \exp \left(\frac{M W_{\text {solution }}}{M W_{\text {pure water }}}\right)\right]+\left[A_{3} \exp \left(m \cdot f_{\mathrm{PVP}}\right)\right]+\left[A_{4} \exp \left(m \cdot f_{\mathrm{MEG}}\right)\right]-\left[A_{5} \ln (P)\right]$

Table 2 The critical properties and acentric factors of the gas mixture components (Perry et al. 2015)

\begin{tabular}{llll}
\hline Component & $\begin{array}{l}\text { Critical temper- } \\
\text { ature } T_{\mathrm{c}}, \mathrm{K}\end{array}$ & $\begin{array}{l}\text { Critical pres- } \\
\text { sure } P_{\mathrm{c}}, \mathrm{MPa}\end{array}$ & Acentric factor $\omega$ \\
\hline $\mathrm{CH}_{4}$ & 190.56 & 4.59 & 0.0115 \\
$\mathrm{C}_{2} \mathrm{H}_{6}$ & 305.32 & 4.87 & 0.0995 \\
$\mathrm{C}_{3} \mathrm{H}_{8}$ & 369.83 & 4.24 & 0.1523 \\
$n-\mathrm{C}_{4}$ & 425.12 & 3.79 & 0.2002 \\
$i-\mathrm{C}_{4}$ & 407.80 & 3.64 & 0.1835 \\
$\mathrm{~N}_{2}$ & 126.20 & 3.40 & 0.0377 \\
$\mathrm{CO}_{2}$ & 304.21 & 7.38 & 0.2236 \\
\hline
\end{tabular}

where $m . f_{\mathrm{PVP}}$ is the mass fraction of PVP in the aqueous solution, $m . f_{\mathrm{MEG}}$ represents the mass fraction of MEG in the aqueous solution, and $P$ is the system's initial pressure in MPa. It is worth mentioning that the role of guest molecule is important in induction time calculation but as we have investigated only one type of gas sample, no parameter for representing the guest molecule is needed to add to the induction time model.

\section{Results and discussion}

Two kinetic parameters were experimentally investigated in this work: the induction time and the gas consumption rate. The definition of the induction time is presented in Fig. 2. 


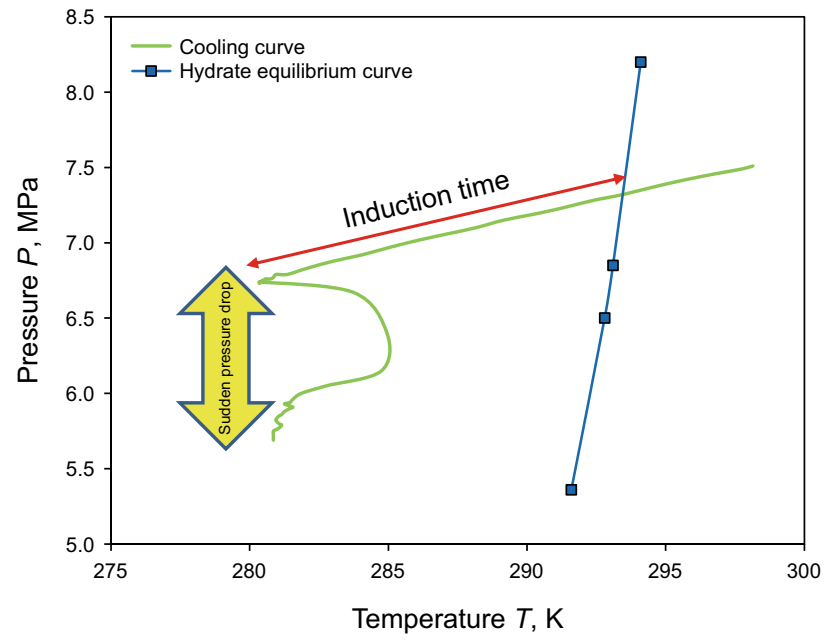

Fig. 2 Representation of induction time in a pressure-temperature diagram

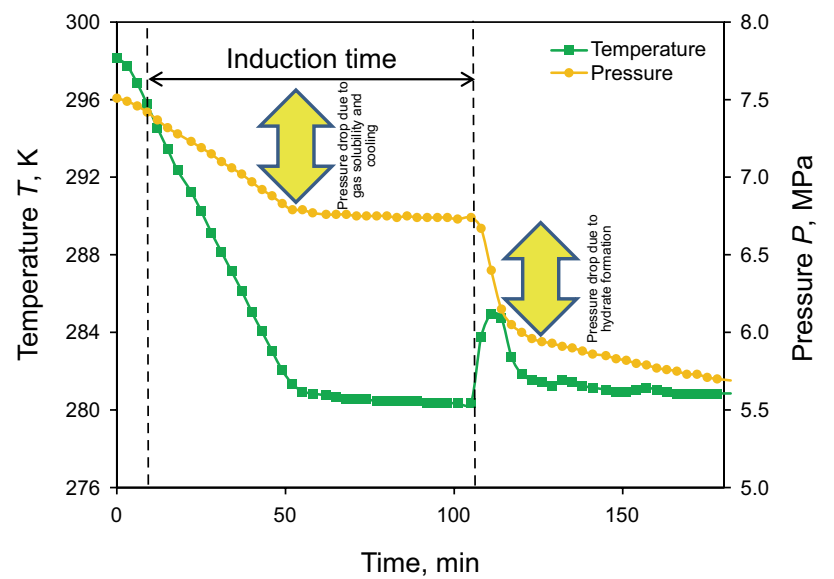

Fig. 3 Temperature and pressure profiles for $1.00 \mathrm{wt} \%$ of PVP in aqueous solution

The hydrate formation in the cell is represented by: (1) A sudden pressure drop in the system because considerable amounts of gas are trapped in hydrate cavities. (2) A sudden peak in temperature profile since hydrate formation is an exothermic reaction that leads to a sudden peak in temperature profile. Figure 3 demonstrates the pressure and temperature profiles for one of our experiments, which are for hydrate formation in the presence of $1.00 \mathrm{wt} \%$ of PVP in aqueous solution. Induction time is also determined in this figure. It is worth mentioning that for several experimental tests in our investigations, no hydrate was formed, therefore, no induction time could be reported.

It is clear from Fig. 3 that, a low-pressure drop has occurred at the beginning of the experiment, which is due to the solubility of gases in the aqueous phase and cooling of the solution. The next pressure drop is due to hydrate formation. Figure 4 exhibits the variations of gas consumption with pressure and temperature in the specified time interval for pure water.

Table 3 presents the natural gas hydrate phase equilibrium temperatures, target temperatures, and subcooling for various aqueous solutions. In the previous studies (Kang et al. 2014; Ke et al. 2016), it was stated that low amounts of LDHIs do not affect hydrate phase equilibrium curves in general. However, some LDHIs may affect hydrate phase equilibrium curves. Since we have no experimental hydrate phase equilibrium data in the presence of the LDHIs at exact pressures and aqueous solution concentrations, therefore, we assumed that the hydrate phase equilibrium conditions in the presence/absence of the LDHIs are the same.

The experiments were conducted at the initial system pressures of 8 and $6 \mathrm{MPa}$. Since hydrate formation is a stochastic phenomenon, for some of the solutions, the experiments were repeated to check the repeatability of the hydrate formation. Tables 4 and 5 indicate the hydrate formation induction times and the gas consumption rates for various cases of water, PVP, MEG, and MEG + PVP mixture solutions. For each aqueous solution, the experiment was repeated more than three times. For several cases, no hydrate was formed and we did not include those obtained results in Tables 4 and 5.

It is interpreted from Tables 3 and 4 that as the subcooling increases, the induction time decreases. The reason is that as the hydrate formation driving force increases by increasing the subcooling, the induction time decreases consequently.

It is obvious from Table 4 that the $1 \mathrm{wt} \%$ PVP and 20 wt $\%$ MEG aqueous mixture has the maximum induction time with the value of $187.5 \mathrm{~min}$ at the target temperature of $277.15 \mathrm{~K}$. By increasing the PVP concentration from 1 $\mathrm{wt} \%$ to $2 \mathrm{wt} \%$ in this aqueous mixture, the induction time decreases. This fact indicates that the aqueous mixture of 1 $\mathrm{wt} \%$ PVP and $20 \mathrm{wt} \%$ MEG is the best choice for hydrate inhibition at the initial pressure of $8 \mathrm{MPa}$. It is noteworthy that the kinetic parameters like the gas hydrate formation induction times are not deterministic phenomena and for the other cases or at different conditions, they would have some variations. The induction time is dependent on several factors like: cooling rate, subcooling, gas composition, aqueous phase concentration, type of additive, pressure, temperature, existence of additive in the system, etc. Even at the same experimental condition for the same solution, different values of induction time are obtained. No deterministic model is available to predict the induction time and in all induction time modeling studies, a semi-empirical or an empirical approach is used and some parameters are fitted using experimental induction time data. It is interpreted from Table 4 that the minimum induction time belongs to the pure water with the value of $35.7 \mathrm{~min}$ at the target temperature of $277.15 \mathrm{~K}$. This shows that MEG, together with PVP, 

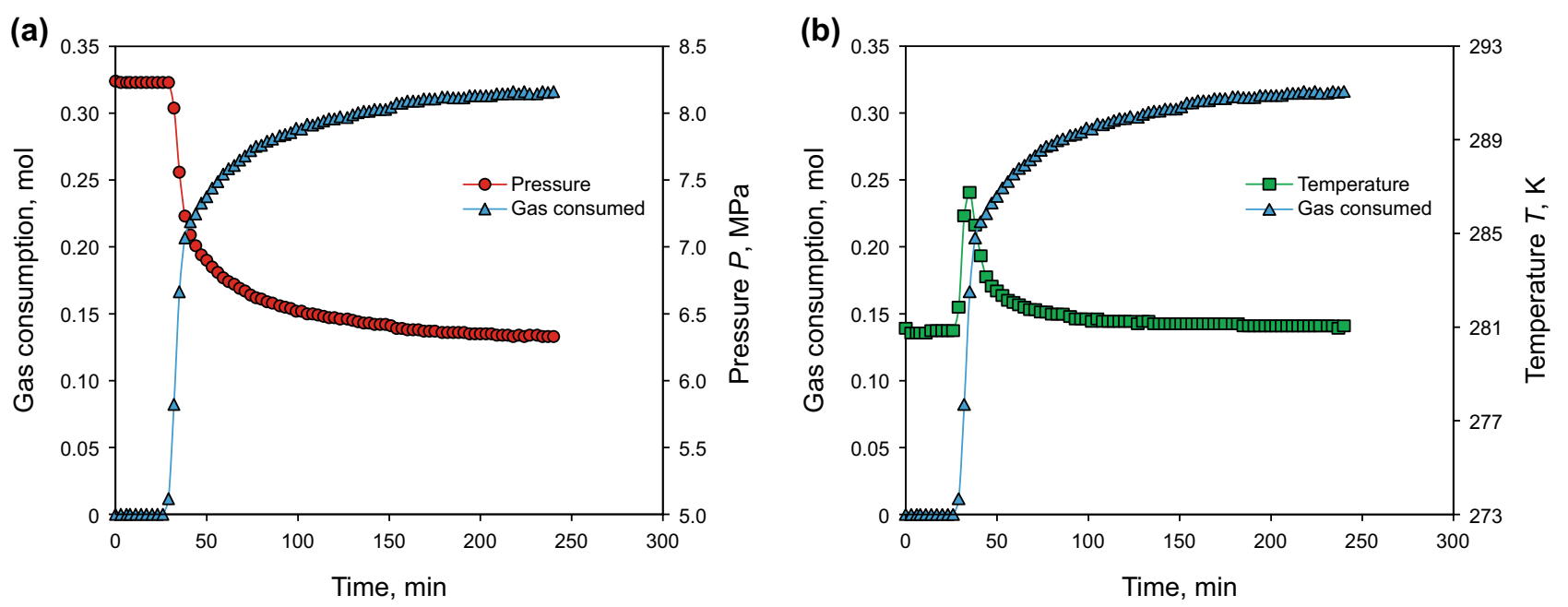

Fig. 4 Variations of gas consumption with pressure and temperature in the specified time interval for pure water

increases the hydrate formation induction time with respect to the pure water and acts as the kinetic hydrate inhibitor. The values of induction time for various concentrations of PVP and MEG are higher than $35.7 \mathrm{~min}$. For instance, at the target temperature of $277.15 \mathrm{~K}, 2 \mathrm{wt} \% \mathrm{PVP}$ has the induction time value of $87.5 \mathrm{~min}$, for $10 \mathrm{wt} \%$ and $20 \mathrm{wt} \%$ MEG the induction time values are 46.3 , and $65.3 \mathrm{~min}$, respectively. For the two solutions ( $1 \mathrm{wt} \% \mathrm{PVP}+10 \mathrm{wt} \%$ MEG and $2 \mathrm{wt} \%$ $\mathrm{PVP}+20 \mathrm{wt} \% \mathrm{MEG}$ ) in Table 4, no hydrate formation was observed and it may be as a result of the probabilistic nature of hydrate formation. Finally, it is clear from Table 4 that for most of the aqueous solutions, MEG by itself has a low to moderate effect on the natural gas hydrate inhibition but acts as a synergist when added to the PVP aqueous solutions.

Table 5 indicates that in a similar manner to the initial pressure of $8 \mathrm{MPa}$, in the initial pressure of $6 \mathrm{MPa}, \mathrm{PVP}$ and MEG increase the hydrate formation induction time values with respect to the pure water. In Table 5, the maximum time is $195 \mathrm{~min}$ for $2 \mathrm{wt} \% \mathrm{PVP}+20 \mathrm{wt} \%$ MEG at the target temperature of $280.15 \mathrm{~K}$ and the minimum induction time is $51.8 \mathrm{~min}$ for pure water at the target temperature of $277.15 \mathrm{~K}$, respectively. For some aqueous solutions, no hydrate formation was observed at the initial pressure of $6 \mathrm{MPa}$. The other results are the same as those obtained from Table 4.

From the view point of the rate of gas consumption in Tables 4 and 5, the results reveal that although PVP aqueous solutions have a great effect on hydrate inhibition, they increase the average rate of gas consumption, which means PVP aqueous solutions control and slow down the nucleation in hydrate formation but they accelerate the hydrate growth rate. Unlike PVP aqueous solutions, MEG aqueous solutions have great effects on the rate of gas consumption and control the hydrate growth rate well. The important conclusion from the rate of gas consumption is that the aqueous mixture of 2 wt $\%$ PVP and $20 \mathrm{wt} \%$ MEG causes a low gas consumption rate. This means that this aqueous mixture simultaneously increases the induction time (control and slow down the nucleation) and decreases the gas consumption rate (control and slow down the hydrate growth rate). This confirms that PVP plays an important role in hydrate nucleation while MEG has a strong effect on hydrate growth rate. This also confirms the fact that the combination of MEG and PVP is a good choice for gas hydrate inhibition from the view point of nucleation and hydrate growth rate control.

In this study, a partly empirical model (Rasoolzadeh et al. 2016; McCabe and Stevens 1951) based on chemical kinetics theory was applied to correlate the natural gas hydrate formation induction time data. Seven parameters in Eqs. (11) and (12) were optimized using the induction time data. Table 6 presents the optimized parameters.

It is concluded from the optimized parameters that increasing the mass fractions of PVP and MEG brings about an increase in the induction time and increasing the initial pressure leads to a decrease in the induction time. One of the advantages of the proposed model is its generalized form from the view points of aqueous solution concentration and pressure. Unlike the previous studies (Rasoolzadeh et al. 2016; Aliabadi et al. 2015), the parameters are not optimized for each solution specifically and the parameters are optimized for all types of aqueous solutions. This may increase the error of the model but makes it more generalized. Table 7 compares the experimental and correlated induction time data for all the solutions.

Figure 5 compares the experimental and correlated induction time data for all the solutions.

The model outputs elucidate that although the hydrate formation induction time is a probabilistic phenomenon, except 
Table 3 Natural gas hydrate phase equilibrium temperatures, target temperatures and subcooling values for different aqueous solutions

\begin{tabular}{|c|c|c|c|c|c|}
\hline Solution & $P_{\text {exp }}, \mathrm{MPa}$ & $T_{\mathrm{s}}, \mathrm{K}$ & $T_{\text {target }}, \mathrm{K}$ & $\Delta T, \mathrm{~K}$ & $\frac{\Delta T}{T_{s}}$ \\
\hline Pure water & 8.00 & 293.97 & 280.15 & 13.82 & 0.0470 \\
\hline Pure water & 8.00 & 293.97 & 277.15 & 16.82 & 0.0572 \\
\hline $1 \mathrm{wt} \% \mathrm{PVP}$ & 8.00 & 293.97 & 280.15 & 13.82 & 0.0470 \\
\hline $2 \mathrm{wt} \% \mathrm{PVP}$ & 8.00 & 293.97 & 280.15 & 13.82 & 0.0470 \\
\hline $2 \mathrm{wt} \%$ PVP & 8.00 & 293.97 & 277.15 & 16.82 & 0.0572 \\
\hline $1 \mathrm{wt} \%$ L-tyrosine & 8.00 & 293.97 & 280.15 & 13.82 & 0.0470 \\
\hline $2 \mathrm{wt} \%$ L-tyrosine & 8.00 & 293.97 & 280.15 & 13.82 & 0.0470 \\
\hline $10 \mathrm{wt} \% \mathrm{MEG}$ & 8.00 & 291.70 & 280.15 & 11.55 & 0.0396 \\
\hline $10 \mathrm{wt} \% \mathrm{MEG}$ & 8.00 & 291.70 & 277.15 & 14.55 & 0.0499 \\
\hline $20 \mathrm{wt} \%$ MEG & 8.00 & 288.99 & 277.15 & 11.84 & 0.0410 \\
\hline Pure water & 6.00 & 292.35 & 280.15 & 12.20 & 0.0417 \\
\hline Pure water & 6.00 & 292.35 & 277.15 & 15.20 & 0.0520 \\
\hline $1 \mathrm{wt} \% \mathrm{PVP}$ & 6.00 & 292.35 & 280.15 & 12.20 & 0.0417 \\
\hline $1 \mathrm{wt} \% \mathrm{PVP}$ & 6.00 & 292.35 & 277.15 & 15.20 & 0.0520 \\
\hline $2 \mathrm{wt} \%$ PVP & 6.00 & 292.35 & 280.15 & 12.20 & 0.0417 \\
\hline $2 \mathrm{wt} \% \mathrm{PVP}$ & 6.00 & 292.35 & 277.15 & 15.20 & 0.0520 \\
\hline $1 \mathrm{wt} \%$ L-tyrosine & 6.00 & 292.35 & 280.15 & 12.20 & 0.0417 \\
\hline $2 \mathrm{wt} \%$ L-tyrosine & 6.00 & 292.35 & 280.15 & 12.20 & 0.0417 \\
\hline $10 \mathrm{wt} \% \mathrm{MEG}$ & 6.00 & 290.12 & 280.15 & 9.97 & 0.0344 \\
\hline $10 \mathrm{wt} \% \mathrm{MEG}$ & 6.00 & 290.12 & 277.15 & 12.97 & 0.0447 \\
\hline $20 \mathrm{wt} \% \mathrm{MEG}$ & 6.00 & 287.46 & 280.15 & 7.31 & 0.0254 \\
\hline $20 \mathrm{wt} \% \mathrm{MEG}$ & 6.00 & 287.46 & 277.15 & 10.31 & 0.0359 \\
\hline $1 \mathrm{wt} \% \mathrm{PVP}+10 \mathrm{wt} \% \mathrm{MEG}$ & 8.00 & 291.70 & 280.15 & 11.55 & 0.0396 \\
\hline $1 \mathrm{wt} \% \mathrm{PVP}+10 \mathrm{wt} \% \mathrm{MEG}$ & 8.00 & 291.70 & 277.15 & 14.55 & 0.0499 \\
\hline $1 \mathrm{wt} \% \mathrm{PVP}+20 \mathrm{wt} \% \mathrm{MEG}$ & 8.00 & 288.99 & 277.15 & 11.84 & 0.0410 \\
\hline $1 \mathrm{wt} \% \mathrm{PVP}+20 \mathrm{wt} \% \mathrm{MEG}$ & 8.00 & 288.99 & 280.15 & 8.84 & 0.0306 \\
\hline $2 \mathrm{wt} \% \mathrm{PVP}+10 \mathrm{wt} \% \mathrm{MEG}$ & 8.00 & 291.70 & 280.15 & 11.55 & 0.0396 \\
\hline $2 \mathrm{wt} \% \mathrm{PVP}+10 \mathrm{wt} \% \mathrm{MEG}$ & 8.00 & 291.70 & 277.15 & 14.55 & 0.0499 \\
\hline $2 w t \%$ PVP + $20 w t \%$ MEG & 8.00 & 288.99 & 280.15 & 8.84 & 0.0306 \\
\hline $1 \mathrm{wt} \% \mathrm{PVP}+10 \mathrm{wt} \% \mathrm{MEG}$ & 6.00 & 290.12 & 277.15 & 12.97 & 0.0447 \\
\hline $1 \mathrm{wt} \% \mathrm{PVP}+10 \mathrm{wt} \% \mathrm{MEG}$ & 6.00 & 290.12 & 280.15 & 9.97 & 0.0344 \\
\hline $1 \mathrm{wt} \% \mathrm{PVP}+20 \mathrm{wt} \% \mathrm{MEG}$ & 6.00 & 287.46 & 280.15 & 7.31 & 0.0254 \\
\hline $1 \mathrm{wt} \% \mathrm{PVP}+20 \mathrm{wt} \% \mathrm{MEG}$ & 6.00 & 287.46 & 277.15 & 10.31 & 0.0359 \\
\hline $2 \mathrm{wt} \% \mathrm{PVP}+10 \mathrm{wt} \% \mathrm{MEG}$ & 6.00 & 290.12 & 280.15 & 9.97 & 0.0344 \\
\hline $2 \mathrm{wt} \% \mathrm{PVP}+10 \mathrm{wt} \% \mathrm{MEG}$ & 6.00 & 290.12 & 277.15 & 12.97 & 0.0447 \\
\hline $2 \mathrm{wt} \% \mathrm{PVP}+20 \mathrm{wt} \% \mathrm{MEG}$ & 6.00 & 287.46 & 280.15 & 7.31 & 0.0254 \\
\hline $2 \mathrm{wt} \% \mathrm{PVP}+20 \mathrm{wt} \% \mathrm{MEG}$ & 6.00 & 287.46 & 277.15 & 10.31 & 0.0359 \\
\hline
\end{tabular}

for a few solutions, the model can correlate the induction time data with acceptable accuracy. This shows the capability of the proposed generalized model in the correlation of hydrate formation induction time data. The errors of the model are calculated as follows (Rasoolzadeh et al. 2016):

$\mathrm{AAE}=\frac{1}{N_{\mathrm{p}}} \sum_{i=1}^{N_{\mathrm{p}}}\left|t_{i}^{\mathrm{exp}}-t_{i}^{\text {model }}\right|$
AARE $=\left(\frac{1}{N_{\mathrm{p}}} \sum_{i=1}^{N_{\mathrm{p}}} \frac{\left|t_{i}^{\text {exp }}-t_{i}^{\text {model }}\right|}{t_{i}^{\exp }}\right) \times 100 \%$

where $N_{\mathrm{p}}$ represents number of data points and $t$ is the induction time. The AAE (average absolute error) and AARE (average absolute relative error) of the model are $16.16 \mathrm{~min}$ and $13.82 \%$, respectively. 
Table 4 Hydrate formation induction time and the rate of gas consumption for different aqueous solutions at $8 \mathrm{MPa}$

\begin{tabular}{|c|c|c|c|c|c|}
\hline Solution & $N_{\mathrm{p}}$ & $\Delta T, \mathrm{~K}$ & $\begin{array}{l}\text { Average induction } \\
\text { time, min }\end{array}$ & Induction time range, min & $\begin{array}{l}\text { Average rate of gas } \\
\text { consumption, mole/ } \\
\text { min }\end{array}$ \\
\hline Pure water & 4 & 13.82 & 47.0 & $28.0-65.0$ & 0.0187 \\
\hline Pure water & 4 & 16.82 & 35.7 & $30.0-53.0$ & 0.0210 \\
\hline $1 \mathrm{wt} \%$ PVP & 2 & 13.82 & 106.5 & $88.0-125.0$ & 0.0162 \\
\hline $2 \mathrm{wt} \% \mathrm{PVP}$ & 2 & 13.82 & 126.5 & $106.0-147.0$ & 0.0233 \\
\hline $2 \mathrm{wt} \% \mathrm{PVP}$ & 2 & 16.82 & 87.5 & $80.0-95.0$ & 0.0183 \\
\hline $10 \mathrm{wt} \% \mathrm{MEG}$ & 2 & 11.55 & 57.0 & $26.0-88.0$ & 0.0102 \\
\hline $10 \mathrm{wt} \% \mathrm{MEG}$ & 3 & 14.55 & 46.3 & $35.0-53.0$ & 0.0124 \\
\hline $20 \mathrm{wt} \%$ MEG & 3 & 11.84 & 65.3 & $53.0-80.0$ & 0.0053 \\
\hline $1 \mathrm{wt} \% \mathrm{PVP}+10 \mathrm{wt} \% \mathrm{MEG}$ & 1 & 11.55 & No hydrate & No hydrate formed & - \\
\hline $1 \mathrm{wt} \% \mathrm{PVP}+10 \mathrm{wt} \% \mathrm{MEG}$ & 1 & 11.55 & Mixer failed & - & - \\
\hline $1 \mathrm{wt} \% \mathrm{PVP}+10 \mathrm{wt} \% \mathrm{MEG}$ & 2 & 14.55 & 89.5 & $77.0-102.0$ & 0.0185 \\
\hline $1 \mathrm{wt} \% \mathrm{PVP}+20 \mathrm{wt} \% \mathrm{MEG}$ & 2 & 11.84 & 187.5 & $187.0-188.0$ & 0.0124 \\
\hline $2 \mathrm{wt} \% \mathrm{PVP}+10 \mathrm{wt} \% \mathrm{MEG}$ & 2 & 11.55 & 82.5 & $77.0-88.0$ & 0.0165 \\
\hline $2 \mathrm{wt} \% \mathrm{PVP}+20 \mathrm{wt} \% \mathrm{MEG}$ & 1 & 8.84 & 170.0 & 170.0 & 0.0063 \\
\hline $2 \mathrm{wt} \% \mathrm{PVP}+20 \mathrm{wt} \% \mathrm{MEG}$ & 1 & 8.84 & Mixer failed & - & - \\
\hline $2 \mathrm{wt} \% \mathrm{PVP}+20 \mathrm{wt} \% \mathrm{MEG}$ & 3 & 11.84 & No hydrate & No hydrate formed & - \\
\hline
\end{tabular}

Table 5 Hydrate formation induction time and the rate of gas consumption for different aqueous solutions at $6 \mathrm{MPa}$

\begin{tabular}{|c|c|c|c|c|c|}
\hline Solution & $N_{\mathrm{p}}$ & $\Delta T, \mathrm{~K}$ & Average induction time, min & Induction time range, min & $\begin{array}{l}\text { Average rate of gas } \\
\text { consumption, mole/ } \\
\text { min }\end{array}$ \\
\hline Pure water & 2 & 12.20 & 64.0 & $35.0-93.0$ & 0.0157 \\
\hline Pure water & 3 & 15.20 & 51.8 & $32.0-125.0$ & 0.0129 \\
\hline $1 \mathrm{wt} \% \mathrm{PVP}$ & 1 & 12.20 & 110.0 & 110.0 & 0.0177 \\
\hline $1 \mathrm{wt} \% \mathrm{PVP}$ & 2 & 12.20 & No hydrate & No hydrate formed & - \\
\hline $1 \mathrm{wt} \% \mathrm{PVP}$ & 1 & 15.20 & 70.0 & 70.0 & 0.0211 \\
\hline $2 \mathrm{wt} \%$ PVP & 1 & 12.20 & 130.0 & 130.0 & 0.0234 \\
\hline $2 \mathrm{wt} \% \mathrm{PVP}$ & 1 & 12.20 & Data was missed due to power failure & & \\
\hline $2 \mathrm{wt} \%$ PVP & 1 & 15.20 & 100.0 & 100.0 & 0.0180 \\
\hline $2 \mathrm{wt} \% \mathrm{PVP}$ & 1 & 15.20 & Leakage from venting connection & & \\
\hline $10 \mathrm{wt} \% \mathrm{MEG}$ & 1 & 9.97 & 115 & 115.0 & 0.0099 \\
\hline $10 \mathrm{wt} \% \mathrm{MEG}$ & 1 & 9.97 & Leakage from venting connection & & \\
\hline $20 \mathrm{wt} \% \mathrm{MEG}$ & 1 & 7.31 & 123.0 & 123.0 & 0.0038 \\
\hline $20 \mathrm{wt} \% \mathrm{MEG}$ & 1 & 10.31 & 80.0 & $75.0-85.0$ & 0.0058 \\
\hline $1 \mathrm{wt} \% \mathrm{PVP}+10 \mathrm{wt} \% \mathrm{MEG}$ & 1 & 9.97 & 85.0 & 85.0 & 0.0160 \\
\hline $1 \mathrm{wt} \% \mathrm{PVP}+10 \mathrm{wt} \% \mathrm{MEG}$ & 1 & 9.97 & No hydrate formed & & \\
\hline $1 \mathrm{wt} \% \mathrm{PVP}+10 \mathrm{wt} \% \mathrm{MEG}$ & 3 & 12.97 & 94.0 & $77.0-103.0$ & 0.0197 \\
\hline $1 \mathrm{wt} \% \mathrm{PVP}+20 \mathrm{wt} \% \mathrm{MEG}$ & 3 & 7.31 & No hydrate & No hydrate formed & - \\
\hline $1 \mathrm{wt} \% \mathrm{PVP}+20 \mathrm{wt} \% \mathrm{MEG}$ & 3 & 10.31 & No hydrate & No hydrate formed & - \\
\hline $2 \mathrm{wt} \% \mathrm{PVP}+10 \mathrm{wt} \% \mathrm{MEG}$ & 2 & 9.97 & 136.5 & $133.0-140.0$ & 0.0082 \\
\hline $2 \mathrm{wt} \% \mathrm{PVP}+10 \mathrm{wt} \% \mathrm{MEG}$ & 2 & 12.97 & 174.0 & $168.0-180.0$ & 0.0191 \\
\hline $2 w t \% \mathrm{PVP}+20 \mathrm{wt} \% \mathrm{MEG}$ & 2 & 7.31 & 195.0 & $150.0-240.0$ & 0.0055 \\
\hline
\end{tabular}


Table 6 The parameters optimized in this work

\begin{tabular}{lr}
\hline Parameter & \multicolumn{1}{c}{ Value } \\
\hline$b$ & 18.297 \\
$m$ & -0.208 \\
$A_{1}$ & -84.034 \\
$A_{2}$ & 0.966 \\
$A_{3}$ & 85.438 \\
$A_{4}$ & 0.014 \\
$A_{5}$ & 1.279 \\
\hline
\end{tabular}

It is worth mentioning that this semi-empirical correlation can only be used for the aforementioned aqueous solutions within the studied pressure and temperature ranges. By comparing the values of AAE and AARE of this work and the errors of several induction time models reported in the literature (Talaghat and Khodaverdiloo 2019), it can be concluded that considering the generalization of the model, the errors are acceptable. Figures 6 and 7 illustrate the average induction time data, the range of experimental data, and the correlated induction time data for various solutions.

It is interpreted from Figs. 6 and 7 that for most of the aqueous solutions, the errors are acceptable. However, for a few solutions, the errors are approximately high, which are due to the weakness of the model in considering the

Table 7 The experimental and correlated induction time data for all the aqueous solutions

\begin{tabular}{|c|c|c|c|c|c|}
\hline Solution & $N_{\mathrm{p}}$ & $\Delta T, \mathrm{~K}$ & $\begin{array}{l}\text { Average induction time } \\
\text { (experimental), min }\end{array}$ & Induction time range, min & $\begin{array}{l}\text { Correlated } \\
\text { induction time, } \\
\text { min }\end{array}$ \\
\hline Pure water & 4 & 13.82 & 47.0 & $28.0-65.0$ & 43.97 \\
\hline Pure water & 4 & 16.82 & 35.7 & $30.0-53.0$ & 38.28 \\
\hline $1 \mathrm{wt} \%$ PVP & 2 & 13.82 & 106.5 & $88.0-125.0$ & 72.08 \\
\hline $2 \mathrm{wt} \% \mathrm{PVP}$ & 2 & 13.82 & 126.5 & $106.0-147.0$ & 100.49 \\
\hline $2 \mathrm{wt} \%$ PVP & 2 & 16.82 & 87.5 & $80.0-95.0$ & 87.50 \\
\hline $10 \mathrm{wt} \% \mathrm{MEG}$ & 2 & 11.55 & 57.0 & $26.0-88.0$ & 57.42 \\
\hline $10 \mathrm{wt} \% \mathrm{MEG}$ & 3 & 14.55 & 46.3 & $35.0-53.0$ & 48.53 \\
\hline $20 \mathrm{wt} \% \mathrm{MEG}$ & 3 & 11.84 & 65.3 & $53.0-80.0$ & 65.30 \\
\hline $1 \mathrm{wt} \% \mathrm{PVP}+10 \mathrm{wt} \% \mathrm{MEG}$ & 1 & 11.55 & No hydrate & No hydrate formed & - \\
\hline $1 \mathrm{wt} \% \mathrm{PVP}+10 \mathrm{wt} \% \mathrm{MEG}$ & 2 & 14.55 & 89.5 & $77.0-102.0$ & 75.69 \\
\hline $1 \mathrm{wt} \% \mathrm{PVP}+20 \mathrm{wt} \% \mathrm{MEG}$ & 2 & 11.84 & 187.5 & $187.0-188.0$ & 96.95 \\
\hline $2 \mathrm{wt} \% \mathrm{PVP}+10 \mathrm{wt} \% \mathrm{MEG}$ & 2 & 11.55 & 82.5 & $77.0-88.0$ & 122.01 \\
\hline $2 \mathrm{wt} \% \mathrm{PVP}+20 \mathrm{wt} \% \mathrm{MEG}$ & 1 & 8.84 & 170.0 & 170.0 & 104.42 \\
\hline $2 \mathrm{wt} \% \mathrm{PVP}+20 \mathrm{wt} \% \mathrm{MEG}$ & 3 & 11.84 & No hydrate & No hydrate formed & - \\
\hline Pure water & 2 & 12.20 & 64.0 & $35.0-93.0$ & 60.70 \\
\hline Pure water & 3 & 15.20 & 51.8 & $32.0-125.0$ & 51.80 \\
\hline $1 \mathrm{wt} \% \mathrm{PVP}$ & 1 & 12.20 & 110.0 & 110.0 & 91.36 \\
\hline $1 \mathrm{wt} \% \mathrm{PVP}$ & 2 & 12.20 & No hydrate & No hydrate formed & - \\
\hline $1 \mathrm{wt} \% \mathrm{PVP}$ & 1 & 15.20 & 70.0 & 70.0 & 77.97 \\
\hline $2 \mathrm{wt} \% \mathrm{PVP}$ & 1 & 12.20 & 130.0 & 130.0 & 122.35 \\
\hline $2 \mathrm{wt} \% \mathrm{PVP}$ & 1 & 15.20 & 100.0 & 100.0 & 104.42 \\
\hline $10 \mathrm{wt} \% \mathrm{MEG}$ & 1 & 9.97 & 115 & 115.0 & 78.66 \\
\hline $20 \mathrm{wt} \% \mathrm{MEG}$ & 1 & 7.31 & 123.0 & 123.0 & 113.37 \\
\hline $20 \mathrm{wt} \% \mathrm{MEG}$ & 2 & 10.31 & 80.0 & $75.0-85.0$ & 86.43 \\
\hline $1 \mathrm{wt} \% \mathrm{PVP}+10 \mathrm{wt} \% \mathrm{MEG}$ & 1 & 9.97 & 85.0 & 85.0 & 114.42 \\
\hline $1 \mathrm{wt} \% \mathrm{PVP}+10 \mathrm{wt} \% \mathrm{MEG}$ & 3 & 12.97 & 94.0 & $77.0-103.0$ & 94.00 \\
\hline $1 \mathrm{wt} \% \mathrm{PVP}+20 \mathrm{wt} \% \mathrm{MEG}$ & 3 & 7.31 & No hydrate & No hydrate formed & - \\
\hline $1 \mathrm{wt} \% \mathrm{PVP}+20 \mathrm{wt} \% \mathrm{MEG}$ & 3 & 10.31 & No hydrate & No hydrate formed & - \\
\hline $2 \mathrm{wt} \% \mathrm{PVP}+10 \mathrm{wt} \% \mathrm{MEG}$ & 2 & 9.97 & 136.5 & $133.0-140.0$ & 150.57 \\
\hline $2 \mathrm{wt} \% \mathrm{PVP}+10 \mathrm{wt} \% \mathrm{MEG}$ & 2 & 12.97 & 174.0 & $168.0-180.0$ & 123.70 \\
\hline $2 \mathrm{wt} \% \mathrm{PVP}+20 \mathrm{wt} \% \mathrm{MEG}$ & 2 & 7.31 & 195.0 & $150.0-240.0$ & 205.64 \\
\hline
\end{tabular}




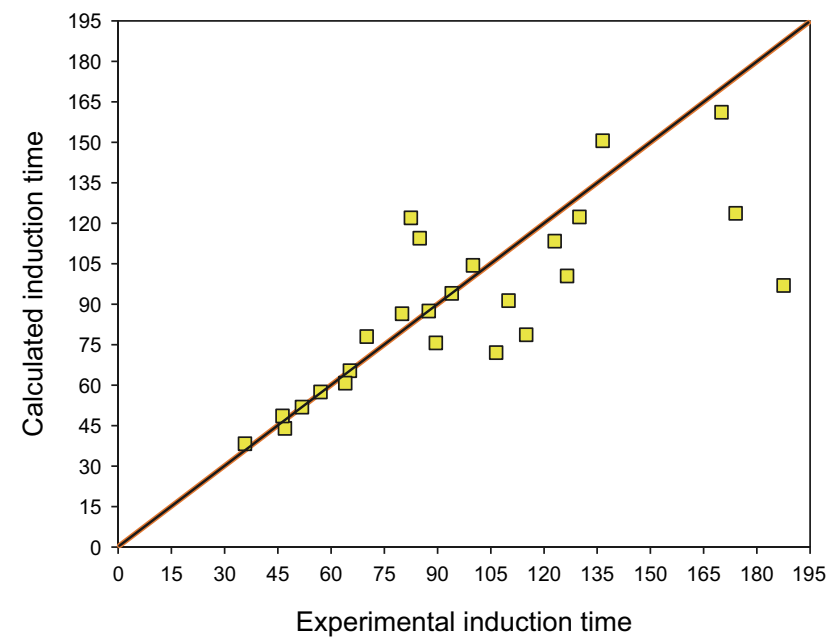

Fig. 5 Resemblance between experimental and calculated induction times for all the aqueous solutions

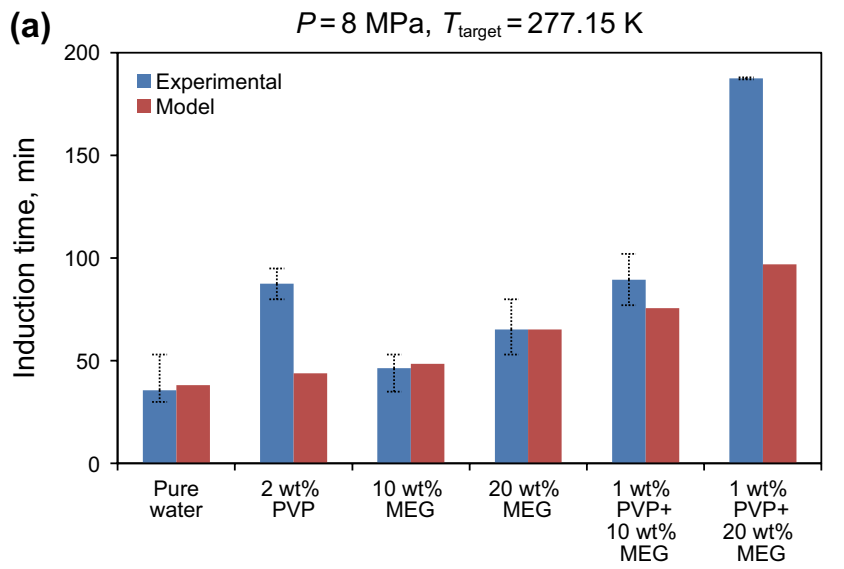

PVP-MEG interactions or inherent errors in the experimental induction time data measured in this work.

The last inhibitor studied in this work is the L-tyrosine. Table 8 indicates the results for L-tyrosine and L-tyrosine + MEG aqueous solutions.

For the case of L-tyrosine aqueous solutions, it is concluded that L-tyrosine aqueous solutions have very weak effects on gas hydrate formation induction time and even decrease in the induction time compared to pure water. These results are in good agreement with the data obtained by Salamat et al. (2013). This shows that from the point of hydrate formation induction time, L-tyrosine is not a good choice. Also, the results show that L-tyrosine + MEG aqueous solution has more inhibition effect on gas hydrate formation induction time. The reason is that the L-tyrosine is a kind of amino-acid and as the $\mathrm{pH}$ of the solution is lowered (in the presence of MEG aqueous solution), the amino acid solubility increases because of the stabilization of the cation species (Carta and Tola 1996). This may increase

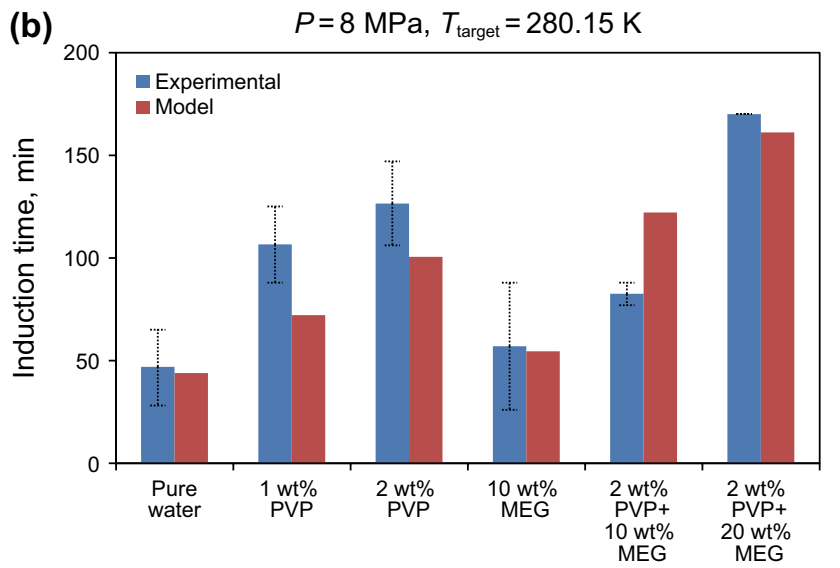

Fig. 6 Experimental and correlated induction time data at the pressure of $8 \mathrm{MPa}$

(a)

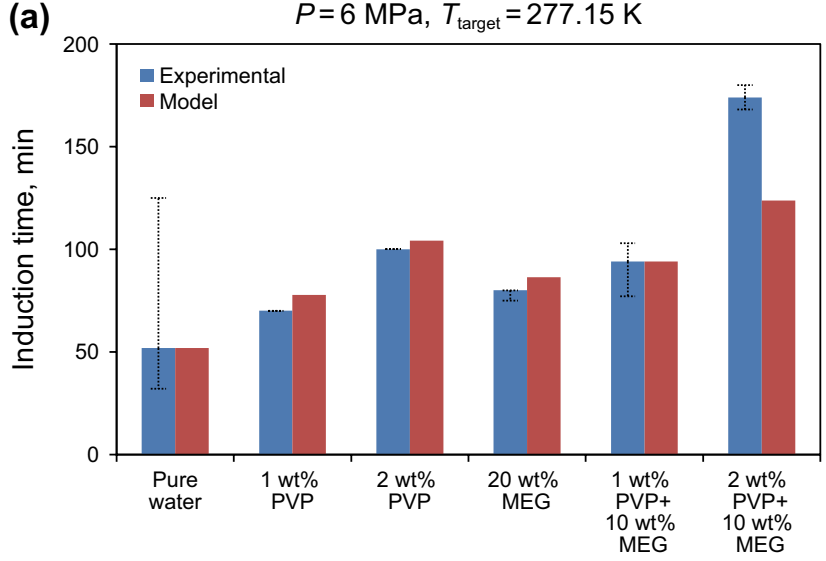

(b) $\quad P=6 \mathrm{MPa}, T_{\text {target }}=280.15 \mathrm{~K}$

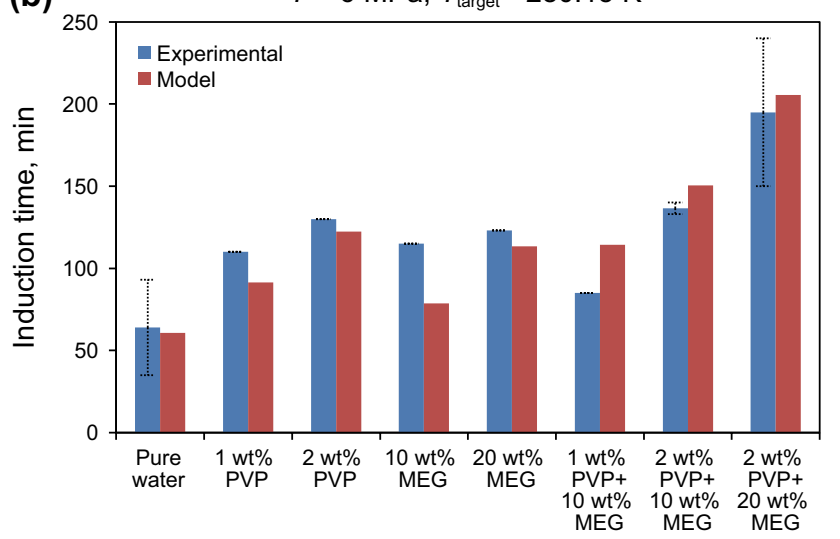

Fig. 7 Experimental and correlated induction time data at the pressure of $6 \mathrm{MPa}$ 
Table 8 Hydrate formation induction time, and the rate of gas consumption for L-tyrosine aqueous solutions

\begin{tabular}{|c|c|c|c|c|c|c|c|c|c|c|c|}
\hline \multirow[t]{2}{*}{ Solution } & \multirow[t]{2}{*}{$P_{\text {exp }}, \mathrm{MPa}$} & \multirow[t]{2}{*}{$T_{\text {eq }}, \mathrm{K}$} & \multirow[t]{2}{*}{$T_{\text {target }}, \mathrm{K}$} & \multicolumn{2}{|c|}{$\begin{array}{l}\text { Number of experi- } \\
\text { ments }\end{array}$} & \multicolumn{2}{|c|}{ Subcooling, K } & \multicolumn{2}{|c|}{$\begin{array}{l}\text { Induction time, } \\
\text { min }\end{array}$} & \multicolumn{2}{|c|}{$\begin{array}{l}\text { Average gas con- } \\
\text { sumption rate, } \\
\text { mole/min }\end{array}$} \\
\hline & & & & Fresh & Used & Fresh & Used & Fresh & Used & Fresh & Used \\
\hline $1 \mathrm{wt} \%$ L-tyrosine & 9.0 & 294.55 & 280.15 & 1 & 5 & 14.4 & $4.8-7$ & 35 & $<25$ & 0.013 & 0.024 \\
\hline $\begin{array}{l}2 \mathrm{wt} \% \\
\text { L-tyrosine }\end{array}$ & 8.64 & 294.15 & 280.15 & 1 & 5 & 14.0 & $5.5-7.3$ & 45 & $<30$ & 0.013 & 0.016 \\
\hline $\begin{array}{l}2 \mathrm{wt} \% \\
\text { L-tyrosine } \\
+10 \mathrm{wt} \% \text { MEG }\end{array}$ & 8.83 & 292.15 & 280.15 & 1 & 4 & 12.0 & $7.5-10.5$ & 53 & $<28$ & 0.010 & 0.012 \\
\hline $\begin{array}{l}2 \mathrm{wt} \% \\
\text { L-tyrosine } \\
+20 \mathrm{wt} \% \text { MEG }\end{array}$ & 8.73 & 289.45 & 280.15 & 1 & 5 & 9.3 & $6.7-8.7$ & 65 & $<32$ & 0.008 & 0.012 \\
\hline
\end{tabular}

the interactions between water and L-tyrosine and results in an increase in the hydrate formation induction time.

Unlike MEG and PVP, fresh and re-used L-tyrosine aqueous solutions even by removing the memory effect, show different results. Although it was expected by lowering the subcooling, the induction time increases, the re-used L-tyrosine aqueous solutions yield lower induction times with respect to fresh L-tyrosine aqueous solutions.

It is concluded that L-tyrosine loses its ability to inhibit hydrate formation after removing its memory effect. It may be due to its structural transition and the polymer property changes. Although the method to remove the memory effect is the same for all the aqueous solutions but the results indicate that L-tyrosine aqueous solutions behave in a different manner in comparison with PVP aqueous solution and pure water. This may be the result of the existence of the alkyl side chain of L-tyrosine. Also, it may be due to the variation of the ion distribution of L-tyrosine, and consequently showing different behavior (Sa et al. 2013). Therefore, L-tyrosine is not a good candidate for natural gas nucleation inhibition. Finally, the results show that although the performance of L-tyrosine is not good in the nucleation step it plays a crucial role in the hydrate crystal growth rate step and decreases the average gas consumption rate significantly. The reason is that L-tyrosine shows different growth inhibition mechanisms compared to PVP. In L-tyrosine, the balance between the effects of the hydrophilic terminal groups and the hydrophobic side chains on the local water structure determines their effectiveness in terms of growth inhibition (Sa et al. 2013). Therefore, L-tyrosine performs successfully in hydrate growth inhibition.

\section{Conclusions}

In this study, the effects of different inhibitors, namely MEG, PVP, and L-tyrosine on two important kinetic parameters including gas hydrate formation induction time and the average rate of gas consumption were investigated. The results elucidate that both MEG and PVP increase the induction times with respect to pure water and PVP is stronger in decreasing the induction times. Adding MEG to PVP, for several cases leads to the synergistic inhibition effect, and for some cases, it deteriorates the inhibition effect. For the case of gas consumption rate, MEG is the better choice compared to PVP. From the point of hydrate formation induction time, L-tyrosine is not a good choice. Also, the results show that L-tyrosine $+\mathrm{MEG}$ leads to more inhibition effect on gas hydrate formation induction time. The reason is that L-tyrosine is a kind of amino-acid and as the $\mathrm{pH}$ of the solution is lowered (in the presence of MEG), the amino acid solubility increases because of the stabilization of the cation species. This may increase the interactions between water and L-tyrosine and result in an increase in the hydrate formation induction time. For the hydrate growth inhibition, L-tyrosine acts well. The reason is that L-tyrosine shows different growth inhibition mechanisms compared to PVP. In L-tyrosine, the balance between the effects of the hydrophilic terminal groups and the hydrophobic side chains on the local water structure determines their effectiveness in terms of growth inhibition. Furthermore, a partly empirical model was used to estimate the induction time for MEG and PVP aqueous solutions. It was concluded that the model can correlate the induction time data with acceptable accuracy.

Open Access This article is licensed under a Creative Commons Attribution 4.0 International License, which permits use, sharing, adaptation, distribution and reproduction in any medium or format, as long as you give appropriate credit to the original author(s) and the source, provide a link to the Creative Commons licence, and indicate if changes were made. The images or other third party material in this article are included in the article's Creative Commons licence, unless indicated otherwise in a credit line to the material. If material is not included in the article's Creative Commons licence and your intended use is not permitted by statutory regulation or exceeds the permitted use, you will need to obtain permission directly from the copyright holder. To view a copy of this licence, visit http://creativecommons.org/licenses/by/4.0/. 


\section{References}

Aliabadi M, Rasoolzadeh A, Esmaeilzadeh F, Alamdari A. Experimental study of using $\mathrm{CuO}$ nanoparticles as a methane hydrate promoter. J Nat Gas Sci Eng. 2015;27:1518-22. https://doi. org/10.1016/j.jngse.2015.10.017.

Carta R, Tola G. Solubilities of L-cystine, L-tyrosine, L-leucine, and glycine in aqueous solutions at various $\mathrm{pHs}$ and $\mathrm{NaCl}$ concentrations. J Chem Eng Data. 1996;41(3):414-7. https://doi. org/10.1021/je9501853.

Cha M, Shin K, Kim J, Chang D, Seo Y, Lee H, et al. Thermodynamic and kinetic hydrate inhibition performance of aqueous ethylene glycol solutions for natural gas. Chem Eng Sci. 2013;99:184-90. https://doi.org/10.1016/j.ces.2013.05.060.

Daraboina N, Linga P, Ripmeester J, Walker VK, Englezos P. Natural gas hydrate formation and decomposition in the presence of kinetic inhibitors. 2. Stirred reactor experiments. Energy Fuels. 2011;25(10):4384-91. https://doi.org/10.1021/ef200813v.

Daraboina N, Malmos C, von Solms N. Synergistic kinetic inhibition of natural gas hydrate formation. Fuel. 2013;108:749-57. https ://doi.org/10.1016/j.fuel.2013.02.018.

Ghaedi H, Javanmardi J, Rasoolzadeh A, Mohammadi AH. Experimental study and thermodynamic modeling of methane hydrate dissociation conditions in the simultaneous presence of BMIM-BF ${ }_{4}$ and ethanol in aqueous solution. J Chem Eng Data. 2018;63(5):1724-32. https://doi.org/10.1021/acs.jced.8b00046.

Haghighi H, Chapoy A, Burgess R, Tohidi B. Experimental and thermodynamic modelling of systems containing water and ethylene glycol: application to flow assurance and gas processing. Fluid Phase Equilib. 2009;276(1):24-30. https://doi.org/10.1021/acs.jced.8b00046.

Haji Nasrollahebrahim ME, Abareshi B, Ghotbi C, Taghikhani V, Amir H. Investigation of six imidazolium-based ionic liquids as thermo-kinetic inhibitors for methane hydrate by molecular dynamics simulation. National Iranian Conference on Gas Hydrate (NICGH), Jul 2013, Tehran, Iran.

Hammerschmidt EG. Formation of gas hydrates in natural gas transmission lines. Ind Eng Chem. 1934;26(8):851-5. https://doi. org/10.1021/ie50296a010.

Hemmingsen PV, Burgass R, Pedersen KS, Kinnari K, Sørensen $\mathrm{H}$. Hydrate temperature depression of MEG solutions at concentrations up to $60 \mathrm{wt} \%$. Experimental data and simulation results. Fluid Phase Equilib. 2011;307(2):175-9. https://doi. org/10.1016/j.fluid.2011.05.010.

Kakati H, Mandal A, Laik S. Synergistic effect of Polyvinylpyrrolidone (PVP) and L-tyrosine on kinetic inhibition of $\mathrm{CH}_{4}+\mathrm{C}_{2} \mathrm{H}_{4}+\mathrm{C}_{3} \mathrm{H}_{8}$ hydrate formation. J Nat Gas Sci Eng. 2016;34:1361-8. https://doi.org/10.1016/j.jngse.2016.08.027.

Kang SP, Shin JY, Lim JS, Lee S. Experimental measurement of the induction time of natural gas hydrate and its prediction with polymeric kinetic inhibitor. Chem Eng Sci. 2014;116:817-23. https://doi.org/10.1016/j.ces.2014.04.035.

Ke W, Svartaas TM, Kvaløy JT, Kosberg BR. Inhibition-promotion: dual effects of polyvinylpyrrolidone (PVP) on structure-II hydrate nucleation. Energy Fuels. 2016;30:7646-55. https://doi. org/10.1021/acs.energyfuels.6b01321.

Kelland MA. History of the development of low dosage hydrate inhibitors. Energy Fuels. 2006;20(3):825-47. https://doi. org/10.1021/ef050427x.

Khan MS, Lal B, Keong LK, Ahmed I. Tetramethyl ammonium chloride as dual functional inhibitor for methane and carbon dioxide hydrates. Fuel. 2019;236:251-63. https://doi.org/10.1016/j. fuel.2018.09.001.

Kim KS, Kang JW, Kang SP. Tuning ionic liquids for hydrate inhibition. Chem Commun. 2011;47:6341-3. https://doi.org/10.1039/ C0CC05676F.
Kim J, Shin K, Seo Y, Cho SJ, Lee JD. Synergistic hydrate inhibition of monoethylene glycol with poly (vinylcaprolactam) in thermodynamically under inhibited system. J Phys Chem B. 2014;118(30):9065-75. https://doi.org/10.1021/jp503435t.

Lee JW, Kang SP. Phase equilibria of natural gas hydrates in the presence of methanol, ethylene glycol, and $\mathrm{NaCl}$ aqueous solutions. Ind Eng Chem Res. 2011;50(14):8750-5. https://doi. org/10.1021/ie2001814.

Lee W, Shin JY, Cha JH, Kim KS, Kang SP. Inhibition effect of ionic liquids and their mixtures with poly (N-vinylcaprolactam) on methane hydrate formation. J Ind Eng Chem. 2016;38:211-6. https://doi.org/10.1016/j.jiec.2016.05.007.

Lim D, Park S, Ro H, Lee JW, Kang H, Kwon M, et al. Thermodynamic and kinetic effect of a dual-function inhibitor on gas hydrate formation. In: The twenty-fourth international ocean and polar engineering conference. International Society of Offshore and Polar Engineers, 2014.

Masoudi R, Tohidi B, Danesh A, Todd AC, Anderson R, Burgass RW, et al. Measurement and prediction of gas hydrate and hydrated salt equilibria in aqueous ethylene glycol and electrolyte solutions. Chem Eng Sci. 2005;60(15):4213-24. https://doi.org/10.1016/j. ces.2005.02.056.

McCabe WL, Stevens RP. Rate of growth of crystals in aqueous solutions. Chem Eng Prog. 1951;47:168-74.

Moeini H, Bonyadi M, Esmaeilzadeh F, Rasoolzadeh A. Experimental study of sodium chloride aqueous solution effect on the kinetic parameters of carbon dioxide hydrate formation in the presence/ absence of magnetic field. J Nat Gas Sci Eng. 2018;50:231-9. https://doi.org/10.1016/j.jngse.2017.12.012.

Mullin JW. Crystallization. 3rd ed. Oxford, U.K.: Butterworth-Heinemann; 1993.

Najibi H, Kamali Z, Mohammadi AH. Phase equilibria of carbon dioxide clathrate hydrates in the presence of methanol/ethylene glycol + single salt aqueous solutions: experimental measurement and prediction. Fluid Phase Equilib. 2013;342:71-4. https://doi. org/10.1016/j.fluid.2013.01.001.

Natarajan V. Thermodynamics and Nucleation Kinetics of Gas Hydrates. Ph.D. Thesis, University of Calgary, Alberta. 1993.

Peng DY, Robinson DB. A new Two-Constant equation of state. Ind Eng Chem Fund. 1976;15(1):59-64. https://doi.org/10.1021/i1600 $57 \mathrm{a} 011$.

Perry RH, Green DW, Maloney JO. Perry's chemical engineers' handbook. New York: McGraw-Hill; 2015.

Qureshi MF, Atilhan M, Altamash T, Tariq M, Khraisheh M, Aparicio $\mathrm{S}$, et al. Gas hydrate prevention and flow assurance by using mixtures of ionic liquids and synergent compounds: combined kinetics and thermodynamic approach. Energy Fuels. 2016;30:3541-8. https://doi.org/10.1021/acs.energyfuels.5b03001.

Rasoolzadeh A, Javanmardi J, Eslamimanesh A, Mohammadi AH. Experimental study and modeling of methane hydrate formation induction time in the presence of ionic liquids. J Mol Liq. 2016;221:149-55. https://doi.org/10.1016/j.molliq.2016.05.016.

Rasoolzadeh A, Javanmardi J, Mohammadi AH. An experimental study of the synergistic effects of BMIM-BF ${ }_{4}, B_{M}$ IM-DCA and TEACl aqueous solutions on methane hydrate formation. Pet Sci. 2019;16(2):409-16. https://doi.org/10.1007/s12182-019-0302-1.

Rimos S, Hoadley AF, Brennan DJ. Determining the economic consequences of natural gas substitution. Energy Convers Manag. 2014;85:709-17. https://doi.org/10.1016/j.encon man.2014.03.012.

Sa JH, Kwak GH, Lee BR, Park DH, Han K, Lee KH. Hydrophobic amino acids as a new class of kinetic inhibitors for gas hydrate formation. Sci Rep. 2013;3:242. https://doi.org/10.1038/srep02428.

Saberi A, Alamdari A, Shariati A, Mohammadi AH. Experimental measurement and thermodynamic modeling of equilibrium condition for natural gas hydrate in MEG aqueous solution. Fluid 
Phase Equilib. 2018;459:110-8. https://doi.org/10.1016/j.fluid .2017.11.034.

Salamat Y, Moghadassi A, Illbeigi M, Eslamimanesh A, Mohammadi AH. Experimental study of hydrogen sulfide hydrate formation: induction time in the presence and absence of kinetic inhibitor. J Energy Chem. 2013;22(1):114-8. https://doi.org/10.1016/S2095 -4956(13)60015-7.

Sloan ED, Koh CA. Clathrate hydrates of natural gases. 3rd ed. Boca Raton: CRC Press Tailor \& Francis Group; 2008.

Talaghat MR, Khodaverdilo AR. Study of different models of prediction of the simple gas hydrates formation induction time and effect of different equations of state on them. Heat Mass Transf. 2019;55(5):1245-55. https://doi.org/10.1007/s00231-018-2508-y.

Tariq M, Rooney D, Othman E, Aparicio S, Atilhan M, Khraisheh M. Gas hydrate inhibition: a review of the role of ionic liquids. Ind Eng Chem Res. 2014;53:17855-68. https://doi.org/10.1021/ ie $503559 \mathrm{k}$.

Villano LD, Kommedal R, Fijten MW, Schubert US, Hoogenboom R, Kelland MA. A study of the kinetic hydrate inhibitor performance and seawater biodegradability of a series of poly (2-alkyl-2-oxazoline) s. Energy Fuels. 2009;23(7):3665-733. https://doi. org/10.1021/ef900172f.

Villicaña-García E, Ponce-Ortega JM. Sustainable strategic planning for a national natural gas energy system accounting for unconventional sources. Energy Convers Manag. 2019;181:382-97. https:// doi.org/10.1016/j.enconman.2018.12.023.

Xiao C, Adidharma H. Dual function inhibitors for methane hydrate. Chem Eng Sci. 2009;64:1522-7. https://doi.org/10.1016/j. ces.2008.12.031.

Xiao C, Wibisono N, Adidharma H. Dialkylimidazolium halide ionic liquids as dual function inhibitors for methane hydrate. Chem Eng Sci. 2010;65:3080-7. https://doi.org/10.1016/j.ces.2010.01.033.

Yaqub S, Lal B, Partoon B, Mellon NB. Investigation of the task oriented dual function inhibitors in gas hydrate inhibition: a review. Fluid Phase Equilib. 2018;477:40-57. https://doi.org/10.1016/j. fluid.2018.08.015. 